\title{
The effect of amodiaquine on some brain macromolecules of Wistar rats
}

\author{
M. B. EKONG ${ }^{1 *}$, A. O. IGIRI ${ }^{1}$, T. B. EKANEM ${ }^{1}$, O. A. EGWU ${ }^{2}$ \\ ${ }^{1}$ Department of Anatomy, Faculty of Basic Medical Sciences, University of Calabar, Calabar, Nigeria. \\ ${ }^{2}$ Department of Anatomy, Faculty of Basic Medical Sciences, College of Health Sciences, Ebonyi State \\ University, Abakaliki, Nigeria. \\ *Corresponding author,Tel: +2348030868505, E-mail: mbe_flashpoint@yahoo.com
}

\begin{abstract}
Amodiaquine (AQ) is a 4-aminoquinoline antimalarial with schizonticidal action against different strains of Plasmodia. This study assessed the effect of the drug on some macromolecules of the brain of albino Wistar rats. Twenty-four adult Wistar rats weighing between 150-180 g were divided into four groups of six animals each. Group 1 served as the control and received distilled water, while groups 2,3 and 4, the experimental groups, were treated with $17.50 \mathrm{mg} / \mathrm{kg}, 8.75 \mathrm{mg} / \mathrm{kg}$ and $8.75 \mathrm{mg} / \mathrm{kg}$ of AQ, respectively. The treatment lasted three days for groups 2 and 3, and six days for group 4. The brains of the animals were removed, weighed and preserved in sucrose tris- $\mathrm{KCl}-\mathrm{MgCl}$ (STKM) buffer for some macromolecule analysis. The total proteins (TP) and triacylglycerol (TAG) showed no significant $(\mathrm{p}>0.05)$ differences between the experimental groups compared to the control, and there was no significant $(p>0.05)$ difference within the experimental groups. In the cholesterol $(\mathrm{CH})$ estimation, the control had significantly $(\mathrm{p}<0.01, \mathrm{p}<0.001)$ higher concentration than groups 3 and 4 respectively, but not group 2. $\mathrm{CH}$ concentration in group 2 was, however, significantly $(\mathrm{p}<0.05, \mathrm{p}<0.01)$ higher than that in groups 3 and 4 respectively. These results reveal that AQ caused insignificant change to brain TP and TAG, but significantly altered the $\mathrm{CH}$ in the brain of Wistar rats. (C) 2008 International Formulae Group. All rights reserved.
\end{abstract}

Keywords: Amodiaquine, Brain, Total protein, Triacylglycerol, Cholesterol, Wistar rats.

\section{INTRODUCTION}

Amodiaquine (AQ) is a 4-aminoquinoline antimalarial drug with a similar mode of action to chloroquine. It has schizonticidal, antipyretic and antiinflammatory properties and is effective against the erythrocytic stages of all four strains of Plasmodia and against some chloroquine-resistant strains (Olliaro et al., 1996; Olliaro and Mussano, 2003). By accumulating in the lysosomes of the parasites, it brings about loss of function, making the parasites unable to digest haemoglobin, which it depends upon for its energy. It also binds to nucleoproteins of the parasites and inhibits their DNA and RNA polymerases (O'Neill et al., 1998).

AQ has been known to cause several adverse reactions (Olliaro et al., 1996; Olliaro and Mussano, 2003). Most of these reactions are not documented because of few scientific researches after the initial withdrawal of the drug. Furthermore, adverse reactions reported previously were mainly associated with the prophylactic use of AQ. Farombi (2000) reported alteration in enzymatic and nonenzymatic antioxidant defense systems, increase in lipid peroxidation and increase in the activities of serum enzymes with AQ treatment, with agranulocytosis and/or hepatitis equally reported (Neftel et al., 1986; Christie et al., 1989).

The increase in resistance to current antimalarial drugs and the adoption of artemisinin-based combination has made the World Health Organization to again list AQ as a drug for treatment of chloroquine-resistant falciparum malaria (Winstanley et al., 1990). 
There have been reports that AQ, though associated with side effects, is very effective, even when used to treat malaria in pregnancy and in children (Tagbor et al., 2006; Adjei et al., 2008). The drug has also been found to elevate histamine level, and partially suppress increases of tumor necrosis factor (TNF)- $\alpha$ in the serum and TNF- $\alpha$ messenger ribonucleic acid (mRNA) expression in the liver (Yokoyamaa et al., 2007).

Different mechanisms of actions have been ascribed to the adverse reactions of AQ. Christie et al. (1989) and Clarke et al. (1990) reported that the adverse reactions of $A Q$ were immune-mediated. Others reported that AQ gives rise to chemically reactive species by at least three distinct mechanisms, viz. autoxidation in neutral solution under air, peroxidase-catalyzed oxidation and Nchlorination (Maggs et al., 1988). Formation of such species in liver and myeloid cells might be responsible for the adverse reactions associated with AQ. This is as reported in an in vitro study where AQ generated free radicals in the form of $\mathrm{AQ}$ quinone immine and semi quinone immine, and these have been implicated in lipid peroxidation in the membranes of hepatocyte cells (Maggs et al. 1988). Though it has been shown in several cases that AQ-induced agranulocytosis occurs via Immune-mediated mechanisms, a direct toxic effect of the drug on abnormally sensitive myeloid progenitor cells has been reported (Aymard et al., 1989). This effect is based on the inhibition of the growth of blood colony forming cells (Rhodes et al., 1986).

Chemically induced neurodegeneration is usually characterised by different patterns of neuronal cell death, gliosis, swollen or destroyed axons, or destruction of the myelin sheath which is usually preceded by biochemical changes (Cavanagh, 1984). Due to this report and some reported effects of AQ on other parts of the body, we investigated the effect of the drug on some macromolecules of the brain.

\section{MATERIALS AND METHODS}

Twenty-four adult Wistar albino rats weighing between 150-180 g were divided into four groups of six animals each. Group 1 served as the control and the animals received distilled water, while groups 2, 3 and 4 served as the experimental groups. The drug, amodiaquine (AQ) was obtained from a reputable pharmacy in Calabar, Nigeria. Each packet of AQ contained twelve blister tablets each of AQ Hydrochloride USP equivalent to AQ base $(153.1 \mathrm{mg}$ ) per tablet. The drug was administered in milligram per kilogram body weight $(\mathrm{mg} / \mathrm{kg})$ to the animals by oral gavage with distilled water as the vehicle. Since AQ dosage is weight dependent; it was interpreted to the physiologic weight of man which is 70 $\mathrm{kg}$, with the recommended dose of the average physiologic weight man being $153.1 \mathrm{mg}$ per day. The drug administration is shown in Table 1.

The animals were sacrificed by cervical dislocation, and their brains were removed, blotted dry on filter papers and weighed using a Mettler p163 balance. The brain of all the animals were homogenised in cold $0.25 \mathrm{M}$ sucrose tris-KCl-MgCl (STKM) buffer.

The homogenisation procedure involved rinsing the brain in cold $0.25 \mathrm{M}$ STKM buffer to remove blood stains, crushing in a mortar and homogenisation in cold 0.25 M STKM buffer. The homogenates were washed into a volumetric flask and made up to $15 \mathrm{ml}$ using the STKM buffer. Aliquots of the homogenates were spurned using a centrifuge. The supernatant of the aliquots were used to estimate; total proteins by Biuret kit method, cholesterol by CHOP-PAP kit method and triacylglycerol by GPO-PAP kit method.

Table 1: The drug administration.

\begin{tabular}{ccc}
\hline $\begin{array}{c}\text { Group } \\
(\mathbf{n = 6})\end{array}$ & Treatment/Dosage per day & $\begin{array}{c}\text { Duration } \\
\text { (days) }\end{array}$ \\
\hline 1 & Distilled water & 3 \\
2 & $17.50 \mathrm{mg} / \mathrm{kg}$ of AQ & 3 \\
3 & $8.75 \mathrm{mg} / \mathrm{kg}$ of AQ & 3 \\
4 & $8.75 \mathrm{mg} / \mathrm{kg}$ of AQ & 6 \\
\hline
\end{tabular}

$\mathrm{AQ}=$ Amodiaquine 
The process involved measuring $0.5 \mathrm{ml}$ of the homogenate and extracting it into 2.5 $\mathrm{ml}$ of chloroform: methanol (2:1) mixture. An aliquot of $0.02 \mathrm{ml}$ was taken and evaporated to dryness at $50{ }^{\circ} \mathrm{C}$. The appropriate reagents were added to each tube of the aliquots. The mixture was allowed to stand at room temperature for about 45 minutes before absorbance reading at $540 \mathrm{~nm}$.

\section{Statistical analysis}

Statistical analysis was carried out using one-way analysis of variance (ANOVA); thereafter student t-test was used to compare the groups and the control. All the results are expressed as mean \pm standard error of mean and values are significant at $\mathrm{p}<0.05$.

\section{RESULTS}

\section{Total proteins}

The control $(2.14 \pm 0.02 \mathrm{~g} / \mathrm{dl})$ was higher than experimental groups $2(2.10 \pm$ $0.05 \mathrm{~g} / \mathrm{dl}), 3(2.05 \pm 0.04 \mathrm{~g} / \mathrm{dl})$ and $4(1.98 \pm$ $0.05 \mathrm{~g} / \mathrm{dl})$, but not significantly $(\mathrm{p}>0.05)$. Group 2 treated with $17.50 \mathrm{mg} / \mathrm{kg}$ of AQ for three days was higher than groups 3 treated with $8.75 \mathrm{mg} / \mathrm{kg}$ of AQ for three days, and 4 treated with $8.75 \mathrm{mg} / \mathrm{kg}$ of AQ for six days. These differences were not significant ( $p>0.05)$. Group 3 was not significantly ( $>0.05$ ) higher than group 4.

\section{Cholesterol}

The control $(229.13 \pm 3.83 \mathrm{mg} / \mathrm{dl})$ was significantly $(\mathrm{p}<0.01, \mathrm{p}<0.001)$ higher than experimental groups $3(206.68 \pm 5.72$ $\mathrm{mg} / \mathrm{dl})$ and $4(202.09 \pm 2.44 \mathrm{~g} / \mathrm{dl})$, respectively, but not group $2(225.11 \pm 1.75$ $\mathrm{mg} / \mathrm{dl})$. Group 2 treated with $17.50 \mathrm{mg} / \mathrm{kg}$ of AQ for three days was significantly $(p<0.05$, $\mathrm{p}<0.01$ ) higher than group 3 treated with 8.75 $\mathrm{mg} / \mathrm{kg}$ of AQ for three days and group 4 treated with $8.75 \mathrm{mg} / \mathrm{kg}$ of AQ for six days, respectively. Group 3 was not significantly ( $>0.05$ ) higher than group 4.

\section{Triacylglycerol}

The control $(120.38 \pm 3.80 \mathrm{mg} / \mathrm{dl})$ was higher than group $3(116.30 \pm 1.03$ $\mathrm{mg} / \mathrm{dl})$ treated with $8.75 \mathrm{mg} / \mathrm{kg}$ of $\mathrm{AQ}$ for three days but lower than groups 2 (129.48 \pm $0.10 \mathrm{mg} / \mathrm{dl}$ ) treated with $17.50 \mathrm{mg} / \mathrm{kg}$ of AQ for three days, and $4(139.20 \pm 12.09 \mathrm{mg} / \mathrm{dl})$ treated with $8.75 \mathrm{mg} / \mathrm{kg}$ of $\mathrm{AQ}$ for six days. These differences were not significant ( $>0.05$ ). Group 4 had the highest value of the estimates.

\section{DISCUSSION}

In this study, the protein estimate of the control was higher than that of the experimental groups but these differences were not significant. The slight change may infer that $\mathrm{AQ}$ at these dosages had little effect on brain proteins. This is in contrast with the results of Ekong et al. (2008) who reported significantly lower levels of proteins in the high dose groups of Amodiaquine (AQ) and artesunate (AS) combination.

The cholesterol $(\mathrm{CH})$ estimate of the control was significantly higher than those of groups 3 and 4 , but not group 2. $\mathrm{CH}$ concentration in group 2 was significantly higher than those in groups 3 and 4 .

AQ causes alterations in the enzymatic and non-enzymatic antioxidant defense system, increases lipid peroxidation and the activities of serum enzymes (Farombi, 2000). The reduced cholesterol in groups 3 and 4 may be due to prolonged exposure to the drug.

Table 2: Total protein, cholesterol, triacylglycerol of rat's brain treated with amodiaquine for three and six days.

\begin{tabular}{|c|c|c|c|c|}
\hline $\begin{array}{c}\text { Group } \\
(n=6)\end{array}$ & Treatment & $\begin{array}{c}\text { Total protein } \\
\text { (g/dl) }\end{array}$ & $\begin{array}{c}\text { Cholesterol } \\
\text { (mg/dl) }\end{array}$ & $\begin{array}{c}\text { Triacylglycerol } \\
\text { (mg/dl) }\end{array}$ \\
\hline 1 & Control & $2.14 \pm 0.02$ & $229.13 \pm 3.83$ & $120.38 \pm 3.80$ \\
\hline 2 & 17.50 of AQ for three days & $2.10 \pm 0.05^{\mathrm{NS}}$ & $225.11 \pm 1.75^{\mathrm{c}, \mathrm{d}}$ & $129.48 \pm 0.10^{\mathrm{NS}}$ \\
\hline 3 & $8.75 \mathrm{mg} / \mathrm{kg}$ of AQ for three days & $2.05 \pm 0.04^{\mathrm{NS}}$ & $206.7 \pm 5.72^{* *}$ & $116.30 \pm 1.03^{\mathrm{NS}}$ \\
\hline 4 & $8.75 \mathrm{mg} / \mathrm{kg}$ of $\mathrm{AQ}$ for six days & $1.98 \pm 0.05^{\mathrm{NS}}$ & $202.09 \pm 2.44^{\text {*** }}$ & $139.20 \pm 12.09^{\mathrm{NS}}$ \\
\hline
\end{tabular}


This is in line with the results of Ekong et al. (2008) who reported reduced cholesterol levels in rats treated especially with higher doses of AQ and AS combination.

The triacylglycerol (TAG) estimate of the control was higher than that of group 3, but lower than those of groups 2 and 4, and these differences were not significant. Alteration in enzymatic and non-enzymatic antioxidant defense systems, increased lipid peroxidation and increased serum enzyme activities following increased AQ administration (Farombi, 2000) may have resulted in stimulating effects on TAG, which are seen in groups 2 and 4. This is in contrast with the results of Ekong et al. (2008) who reported higher levels of TAG in the high doses of AQ and AS combination. Ikeda et al. (1988) reported increased brain TAG on rats subjected to hypoxia which later decreased on recovery. The drug may also have affected adrenocorticotropin hormone level whose increase stimulates the synthesis of brain TAG (Arnaud et al., 2006). Sun (1972) had earlier reported marked alterations in acyl group compositions of major phosphoglycerides from whole brain homogenates in rat maintained on fatty acid deficient diet.

The level of these macromolecules in the brain determines the functional well being of individuals since brain TP serve as working molecule of the cells, and the lipids, though function in myelination, also serve as a source of energy (Darnell et al., 1990; Mayes, 2000).

In conclusion, these results reveal that AQ caused insignificant change to brain TP and TAG, but significantly altered the $\mathrm{CH}$ in the brain of Wistar rats. This finding does not justify wrong usage of the drug because prolonged and unregulated use of the drug may precipitate these macromolecules, which may subsequently disrupt the brain's function.

\section{REFERENCES}

Adjei GO, Kristensen K, Goka BQ, Hoegberg LC, Alifrangis M, Rodrigues OP, Kurtzhals JA. 2008. Effect of concomitant artesunate administration and CYP2C8 polymorphisms on the pharmacokinetics of amodiaquine in Ghanaian children with uncomplicated malaria. Antimicrob. Agents Chemother., Sep 8. [Epub ahead of print].
Arnaud J, Nobile O, Boyer J. 2006. On the similarity of triacylglycerol and acetylcholesterol lipases in rat brain. $J$. Neurochem., 41(6): 1558-1562.

Aymard JP, Rouveix B, Ferry R, Janot C, May T, Legras B, Streiff F. 1989. Amodiaquine-induced agranulocytosis: Report of a case with in vitro studies of granulocyte-macrophage progenitor cells. Acta. Haematologic., 82(1): 40-42.

Cavanagh J B. 1984. The problems of neurons with long axons. Lancet. 25(1): 12841287.

Christie G, Breckenridge AM, Park BK. 1989. Drug-protein conjugates-XVIII. Detection of antibodies its quinone imine metabolite in man and rat. Biochem. Pharmacol., 38(9): 1451-1458.

Clarke JB, Maggs JL, Kitteringham NR, Park BK. 1990. Immunogenicity of amodiaquine in the rat. Intern. Arch Allergy Appl. Immunol., 91(4): 335-342.

Darnell J, Lodish H, Baltimore D. 1990. Molecular Cell Biology. Scientific American Books, Inc: New York.

Ekong MB, Igiri AO, Ekanem TB, Ekam VS, Ekeoma, AO. 2008. Effect of amodiaquine plus artesunate combination on some macromolecules in the brain of albino Wistar rats. I. J. Health., 2(1).

Farombi EO. 2000. Influence of amodiaquine treatment on microsomal lipid peroxidation and antioxidant defense systems of rats. Ann. Rev. Pharmacol. Toxicol., 87(6): 249-254.

Ikeda M, Busto R, Yoshida S, Santiso M, Martinez E, Ginsberg MD. 1998. Cerebral phosphoinositide, triacylglycerol and energy metabolism during severe hypoxia and recovery. Brain Res., 459(2): 344-350.

Maggs JL, Tingle MD, Kitteringham NR, Park BK. 1988. Drug-protein conjugatesXIV. Mechanisms of formation of protein-arylating intermediates for amodiaquine, a myelotoxin and hepatotoxin in man. Biochem. Pharmacol., 37(2): 303-311.

Mayes PA. 2000. Lipid of physiologic significance. In Harper's Biochemistry, Murray RK, Granner DK, Mayes PA, Rodwell VW. (eds). Mecurant-Hill: New York; 160-171. 
Neftel KA, Woodtly W, Schmid M, Frick PG, Fehr J. 1986. Amodiaquine induced agranulocytosis and liver damage. $\mathrm{Br}$. Med. J., 292(6522): 721-723.

O’Neill PM, Bray PG, Hawley SR, Ward SA, Park BK. 1998. 4-aminoquinolines-past, present, and future; a chemical perspective. Pharmacol. Ther., 77: 29-58.

Olliaro P, Mussano P. 2003. Amodiaquine for Treating Malaria. The Cochrane Database of System Reviews: In the Cochrane Library. John Wiley and Sons, Ltd: Chichester.

Olliaro P, Nevill C, LeBras J, Ringwald P, Mussano P, Garner P, Brasseur P. 1996. Systematic review of amodiaquine treatment in uncomplicated malaria. Lancet., 348(9036): 1160-1196.

Rhodes EG, Ball J, Franklin IM. 1986. Amodiaquine induced agranulocytosis: inhibition of colony growth in bone marrow by antimalarial agents. $\mathrm{Br}$. Med. J., 292(6522): 717-718.

Robert A, Benoit-Vical F, Dechy-Cabaret O, Meunier B. 2001. From classical antimalarial drugs to new compounds based on the mechanism of action of artemisinin. Pure Appl. Chem., 73(7): 1173-1188.

Sun GY. 1972. Effect of a fatty acid deficiency on lipids of whole brain, microsomes, and myelin in the rat. $J$. Lipid Res., 13: 56-62.

Tagbor H, Bruce J, Browne E, Randal A, Greenwood B, Chandramohan D. 2006. Efficacy, safety, and tolerability of amodiaquine plus sulphadoxinepyrimethamine used alone or in combination for malaria treatment in pregnancy: a randomised trial. Lancet., 368(9544): 1349-1356.

Winstanley PA, Simooya O, Kofi-Ekwe JM, Walker O, Salako LA, Edwards G, Orme ML, Breckenridge AM. 1990. The disposition of amodiaquine in Zambians and Nigerians with malaria. Br. J. Clin. Pharmacol., 29: 695-701.

Yokoyamaa A, Moria S, Takahashia HK, Kankea T, Wakea H, Nishibori. M. 2007. Effect of amodiaquine, a histamine Nmethyltransferase inhibitor, on, Propionibacterium acnes and lipopolysaccharideinduced hepatitis in mice. Eur. J. Pharmacol., 558(1-3): 179-184. 